\section{The Microstructure of the Brazilian Market for Corporate Bonds}

\author{
Antonio Gledson de Carvalho' \\ ${ }^{1}$ Getúlio Vargas Foundation (FGV), São Paulo School of \\ Business Administration, São Paulo, Brazil \\ Felipe Tumenas Marques ${ }^{2}$ \\ ${ }^{2}$ Federal University of Bahia (UFBA), School of \\ Administration, Salvador, Brazil
}

\begin{abstract}
Purpose - The Brazilian government approved regulations to foster the corporate bond market. In 2009, Instruction 476 of the Comissão de Valores Mobiliários (the Brazilian capital market regulator) relaxed the requirements for issuing bonds. In 2011, Law 12,431 created infrastructure bonds, which give individuals tax exemptions. Since then, aggregate proceeds have more than tripled. We describe the Brazilian bond market and the characteristics of issues and issuers; and critically evaluate this evolution.
\end{abstract}

Design/methodology/approach - Descriptive analysis. Data on aggregate issuances; bond characteristics (proceeds, maturity, yields, underwriting); issuer characteristics; secondary market (trading); performance (default and renegotiation rates); and allocation of issues.

Findings - Bond issues are small and bonds present a short maturity. International agencies are the main ratings providers, using a Brazilianadjusted rating scale. Fixed-yield bonds are rare. The vast majority of regular bonds are linked to the interbank offered interest rate (DI or CDI). Only two local universal banks dominate the underwriting activity. These banks and their related parties receive more than half of the aggregate allocation. Less than half of issues have an investment grade, and more than half are not rated at all. The incidence of expost credit events is most frequently in the form of renegotiations of bond terms. Strict defaults are also high. Liquidity for bonds in the secondary market is low.

Originality/value - To our knowledge, this is the first article to describe the microstructure of the Brazilian bond market.

Keywords - Brazil, bonds, bond market, capital markets
Received on

06/09/2018

Approved on

$06 / 28 / 2019$

Responsible editor:

Prof. Dr. Joelson Oliveira

Sampaio

Evaluation process:

Double Blind Review

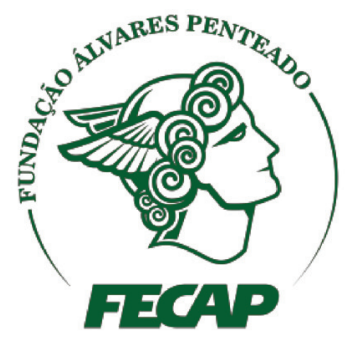

Revista Brasileira de Gestáo de Negócios 


\section{Introduction}

The microstructure of bond markets is a subject of research in a wide range of markets. In the United States, Fleming and Krishnan (2012) study government bonds, and Biais and Green (2019) examine corporate and municipal bonds. In Asia and Africa, Gyntelberg, Ma, and Remolona (2006) and Mo, Phelps, and Stotsky (2013) have also investigated the topic. Some authors have found key factors for the development of a corporate bond market. Ong (2005) indicates that good corporate governance fosters the development of local bond markets, while high levels of government debt issuance have the opposite effect. Hawkins (2002) points out that banks have a crucial role in bond markets in emerging economies. First, banks are competitors, because bond markets can replace bank lending and reduce deposits in banks. Second, banks play an important role in the allocation and issuance of corporate bonds.
This creates conflicts of interest among lending, underwriting, and asset management activities. Nonetheless, there is a paucity of studies on the Brazilian bond market and its role in the funding of non-financial corporations. This article starts to fill this gap, providing a description of the microstructure of the Brazilian bond market.

Credit to non-financial corporations (CNFC) in Brazil has been low (Carvalho, 2005; Torres \& Macahyba, 2014). Table 1 illustrates this point. It reports $\mathrm{CNFC}$ as a percentage of GDP from 2005 to 2017. CNFC in Brazil ranges from $35 \%$ to $40 \%$ of GDP. This is below the averages for emerging markets, the G20, and other BRIC (Brazil, Russia, India, and China) countries. For decades, the low CNFC has been a concern for the Brazilian government. Several measures have been undertaken to improve CNFC, most notably the revision of the Bankruptcy Law in 2005 (Law n. $11,101,2005)$, which increased creditors' rights.

Table 1

\section{Credit to Non-Financial Corporations, as a percentage of GDP}

\begin{tabular}{lcccccc}
\hline & Brazil & Russia & India & China & Emerging Markets & G20 Countries \\
\hline $\mathbf{2 0 0 5}$ & 37,6 & 31,0 & n.d. & n.d. & n.d. & n.d. \\
$\mathbf{2 0 0 6}$ & 40,1 & 31,7 & n.d. & 106,5 & n.d. & n.d. \\
$\mathbf{2 0 0 7}$ & 35,1 & 39,0 & 42,3 & 96,8 & n.d. & n.d. \\
$\mathbf{2 0 0 8}$ & 41,6 & 42,8 & 46,2 & 96,3 & 56,3 & 78,1 \\
$\mathbf{2 0 0 9}$ & 42,2 & 47,2 & 47,3 & 119,9 & 73,5 & 86,9 \\
$\mathbf{2 0 1 0}$ & 42,4 & 41,9 & 50,3 & 120,7 & 72,1 & 83,3 \\
$\mathbf{2 0 1 1}$ & 42,2 & 41,3 & 50,4 & 119,9 & 69,8 & 79,9 \\
$\mathbf{2 0 1 2}$ & 44,0 & 39,8 & 51,9 & 130,6 & 78,0 & 84,0 \\
$\mathbf{2 0 1 3}$ & 46,4 & 43,1 & 52,2 & 140,7 & 84,7 & 86,2 \\
$\mathbf{2 0 1 4}$ & 47,5 & 53,8 & 50,3 & 149,9 & 88,7 & 84,5 \\
$\mathbf{2 0 1 5}$ & 49,2 & 57,9 & 50,3 & 162,7 & 99,0 & 91,0 \\
$\mathbf{2 0 1 6}$ & 45,9 & 51,5 & 46,3 & 166,4 & 101,7 & 91,6 \\
$\mathbf{2 0 1 7}$ & 43,9 & 49,3 & 44,7 & 160,3 & 104,6 & 96,2 \\
\hline
\end{tabular}

Source: Bank of International Settlements (http://stats.bis.org).n.a.: not available.

The Brazilian corporate bond market, as part of CNFC, has also had little relevance (Carvalho, 2000; Torres \& Macahyba, 2014). Table 2 reports yearly aggregate bond issuance from 2005 to 2017 . In the 2005-2008 period, bond issuance was very modest. Proceeds averaged BRL 14.5 billion per year (nearly 44 issues per year), representing, on average, only $0.6 \%$ of GDP and $5.3 \%$ of CNFC. 
Table 2

Bond Issuance over Time

\begin{tabular}{|c|c|c|c|c|c|c|c|}
\hline \multirow{2}{*}{ Year } & \multirow{2}{*}{$\begin{array}{c}\text { Total } \\
\text { BRL bn } \\
\text { (\# issues) }\end{array}$} & \multicolumn{2}{|c|}{ Percentage of } & \multicolumn{2}{|c|}{ Regular bonds (\%) } & \multicolumn{2}{|c|}{ Infra bonds (\%) } \\
\hline & & GDP & CNFC & CVM-400 & CVM-476 & CVM-400 & CVM-476 \\
\hline 2005 & $\begin{array}{c}14 \\
(46)\end{array}$ & 0,66 & 6,69 & $\begin{array}{c}100 \\
(100)\end{array}$ & & & \\
\hline 2006 & $\begin{array}{c}22 \\
(42)\end{array}$ & 0,92 & 8,51 & $\begin{array}{c}100 \\
(12,4)\end{array}$ & & & \\
\hline 2007 & $\begin{array}{c}13 \\
(49)\end{array}$ & 0,49 & 3,90 & $\begin{array}{c}100 \\
(14,4)\end{array}$ & & & \\
\hline 2008 & $\begin{array}{c}9 \\
(37)\end{array}$ & 0,29 & 1,90 & $\begin{array}{c}100 \\
(10,9)\end{array}$ & & & \\
\hline 2009 & $\begin{array}{c}29 \\
(113)\end{array}$ & 0,88 & 6,04 & $\begin{array}{c}45 \\
(11,8)\end{array}$ & $\begin{array}{c}55 \\
(3,5)\end{array}$ & & \\
\hline 2010 & $\begin{array}{c}55 \\
(197)\end{array}$ & 1,41 & 9,88 & $\begin{array}{c}29 \\
(10,0)\end{array}$ & $\begin{array}{c}71 \\
(7,8)\end{array}$ & & \\
\hline 2011 & $\begin{array}{c}52 \\
(210)\end{array}$ & 1,20 & 8,01 & $\begin{array}{c}6 \\
(4,4)\end{array}$ & $\begin{array}{c}94 \\
(9,4)\end{array}$ & & \\
\hline 2012 & $\begin{array}{c}92 \\
(321)\end{array}$ & 1,90 & 12,96 & $\begin{array}{c}16 \\
(10,0)\end{array}$ & $\begin{array}{c}79 \\
(13,4)\end{array}$ & $\begin{array}{c}1 \\
(3,6)\end{array}$ & $\begin{array}{c}4 \\
(6,6)\end{array}$ \\
\hline 2013 & $\begin{array}{c}71 \\
(346)\end{array}$ & 1,33 & 9,30 & $\begin{array}{c}11 \\
(7,1)\end{array}$ & $\begin{array}{c}81 \\
(14,4)\end{array}$ & $\begin{array}{c}5 \\
(19,6)\end{array}$ & $\begin{array}{c}4 \\
(10,4)\end{array}$ \\
\hline 2014 & $\begin{array}{c}123 \\
(354)\end{array}$ & 2,12 & 15,46 & $\begin{array}{c}2 \\
(1,8)\end{array}$ & $\begin{array}{c}94 \\
(15,3)\end{array}$ & $\begin{array}{c}2 \\
(17,9)\end{array}$ & $\begin{array}{c}2 \\
(18,9)\end{array}$ \\
\hline 2015 & $\begin{array}{c}66 \\
(270)\end{array}$ & 1,10 & 7,92 & $\begin{array}{c}11 \\
(2,1)\end{array}$ & $\begin{array}{c}79 \\
(11,4)\end{array}$ & $\begin{array}{c}5 \\
(19,6)\end{array}$ & $\begin{array}{c}4 \\
(14,2)\end{array}$ \\
\hline 2016 & $\begin{array}{c}60 \\
(243)\end{array}$ & 0,96 & 8,07 & $\begin{array}{c}0 \\
(0,6)\end{array}$ & $\begin{array}{c}92 \\
(10,3)\end{array}$ & $\begin{array}{c}3 \\
(10,7)\end{array}$ & $\begin{array}{c}5 \\
(19,8)\end{array}$ \\
\hline 2017 & $\begin{array}{c}95 \\
(354) \\
\end{array}$ & 1,46 & 13,02 & $\begin{array}{c}3 \\
(1,2) \\
\end{array}$ & $\begin{array}{c}88 \\
(14,5) \\
\end{array}$ & $\begin{array}{c}4 \\
(28,6)\end{array}$ & $\begin{array}{c}6 \\
(36,2)\end{array}$ \\
\hline Total & & & $\begin{array}{l}\text { BRL bn } \\
\text { (\# issues) }\end{array}$ & $\begin{array}{l}125,7 \\
(340)\end{array}$ & $\begin{array}{c}542,0 \\
(2.080)\end{array}$ & $\begin{array}{l}15,4 \\
(56)\end{array}$ & $\begin{array}{c}19,3 \\
(106)\end{array}$ \\
\hline
\end{tabular}

Year total amount issued in BRL billions, year total number of issues (in parentheses), percentage of year total in BRL billions, and percentage of year total issues (in parentheses). Infra bonds: bonds issued to fund priority infrastructure projects (created by Law 12,431 of 2011); Regular bonds: non-infra bonds; CVM-400: bonds issued under Instruction CVM-400 (registration required and broad distribution); and CVM-476: bonds issued under Instruction CVM-476 (registration not required and distribution restricted to a limited number of professional investors); $C N F C$ : credit to non-financial corporations. Source: Brazilian Association of Capital Market Participants (ANBIMA). Available at www.debentures.com.br.

Until 2009, the only mechanism through which bonds could be issued was CVM-400 (Instrução CVM n. 400, 2003) of the Comissão de Valores Mobiliários (the Brazilian securities and exchange commission). Under it, issues needed to be registered at the CVM and prospectuses needed to be very detailed. In 2009, with the purpose of fostering the corporate bond market, the CVM issued CVM-476 (Instrução CVM n. 476, 2008). This new regulation created an alternative, simplified procedure for bond issuance. CVM476 does not require previous issue registration at the CVM. With the same purpose, Law 12,431 of 2011 created infrastructure bonds (or infra bonds) with tax exemption for individual and foreign investors.

CVM-476 and infra bonds together caused a significant change in the size of the bond market. As Table 2 shows, in the 2009-2017 period, yearly proceeds increased to BRL 71.4 
billion per year (nearly 270 issues per year). These numbers, when compared to those of the 20052008 period, represent a $0.8 \%$ jump in term of GDP (from $0.6 \%$ to $1.4 \%$ ) and $5 \%$ in terms of CNFC (from $5 \%$ to $10 \%$ ).

CVM-476 and infra bonds together caused a significant change in the structure of the bond market. Over the 2009-2017 period, bonds issued under CVM-476 became predominant, accounting for $87 \%$ of the proceeds and $82 \%$ of the number of issues. Issuance of infra bonds began in 2012. During the 2012-2017 period, infra bonds accounted for $7 \%$ of the proceeds and the number of issues. After 2014, CVM-400 became less relevant for the issuance of regular bonds (i.e. non-infra bonds). As Table 1 reports, during the 2015-2017 period, it accounts for less than $10 \%$ of issuances. However, CVM-400 is still significant for the issuance of infra bonds. It accounted for $44 \%$ of the proceeds $(35 \%$ of the number of issues) of the infra bonds issued between 2012 and 2017 .

The rapid change in the size and structure of the Brazilian bond market motivates this article. We aim to provide a broad picture of this market. Section 2 briefly describes the legal provisions for bond issuance. Section 3 presents our data sources. Section 4 explores the characteristics of bond issues and their performance. Finally, Section 5 critically evaluates the recent changes that occurred in the bond market.

\section{Brazilian provisions and regulations for bonds issuances}

The Brazilian regulations have two provisions for bond issuances, both established by the Brazilian Securities and Exchange Commission (Comissão de Valores Mobiliários, CVM). These provisions are known as CVM Instruction 400 (Instrução CVM n. 400, 2003) and CVM Instruction 476 (Instrução CVM n. 476, 2008).

CVM-400, issued in 2003, regulates the traditional form of bond issuance. To begin with, issues must be previously registered at the CVM. Issuers must be public corporations ${ }^{1}$ (empresas abertas, in Portuguese) and fill in a detailed prospectus. The prospectus contains: (i) complete information on the issuer's business, main advantages, and competitive strategies; (ii) a description of the issuer's five main risk factors, in order of relevance; (iii) details on the uses of the proceeds; and (iv) financial statements for the previous three years. Bonds issued under CVM400 can be distributed to any investor and bear no restriction on trading. The only exception applies to bonds of pre-operational issuers that cannot be floated within the first eight months after issuance. These pre-operational bonds can only be distributed among qualified investors (QIs, with more than BRL 1 million invested in securities).

In 2009, the CVM issued CVM-476, which provides a broader, faster, and cheaper track for bond issuance than CVM-400. Under CVM-476, issuers are not required to be public corporations, and neither a detailed prospectus nor registration at the CVM are needed. However, some constraints apply: distribution is restricted to professional investors (PIs, with investments in securities of more than BRL 10 million); the prospectus can be distributed to at most 75 PIs; the issue can be divided among 50 PIs at most; ${ }^{2}$ and bonds cannot be floated within the first 90 days after the issuance. However, after this lockup period, QIs can also trade the bond.

In 2011, Law 12,431 created infrastructure bonds (infra bonds). The proceeds of these bonds must be used to fund infrastructure projects. Before issuing infra bonds, corporations must have their projects approved by the government. Infra bond maturity cannot be less than 4 years. The interval between coupon payments cannot be less than 180 days. Infra bonds can be inflationlinked (effective interest rate pegged to the consumer price index, the IPCA), but not interest rate-linked. Only Specific Purpose Entities (SPE) are allowed to issue floating-rate infra bonds. In this case, the rate is pegged to the Brazilian interbank offered interest rate, the CDI (certificado de depósito interbancário, in Portuguese). During the first two years after issuance, issuers cannot 
trade in their own infra bonds. Call provisions are not allowed. Infra bonds can be issued under both CVM-400 and CVM-476. Individuals (pessoas fisicas, in Portuguese) and foreign investors are tax-exempt and legal entities (pessoas jurídicas, in Portuguese) pay a $15 \%$ rather than the usual $25 \%$ tax rate.

\section{Data}

The prospectuses and data on aggregate issuances, the characteristics of issuances, the secondary market, defaults, and renegotiations come from the Brazilian Association of Financial and Capital Market Entities (Associação Brasileira das Entidades dos Mercados Financeiros e de Capitais, ANBIMA). ${ }^{3}$ The data on the placement of the issuances come from the offer-closing announcements (anúncios de encerramento de oferta). ${ }^{4}$

\section{The bond market}

\section{I Bond characteristics}

In this section, we characterize bonds issued in Brazil from 2009 to 2017.

Maturity: Table 3 lists the maturities of the different types of bonds. The last column reports aggregate values. The majority of the bonds (53\% of the proceeds and $46 \%$ of the number of issues) have a maturity of between 5 and 10 years. Maturity between 3 and 5 years (22\% of the proceeds and $20 \%$ of the number of issues) or below 3 years (22\% of the number of issues, but only $14 \%$ of the proceeds) are also common. As expected, infra bonds have a longer maturity than regular bonds. Only rarely do they have a maturity below 5 years (their maturity cannot be less than 4 years).

Table 3

\section{Bond Maturity}

\begin{tabular}{|c|c|c|c|c|c|c|}
\hline \multicolumn{7}{|c|}{ Sample period 2009-2017 } \\
\hline \multirow{2}{*}{\multicolumn{2}{|c|}{$\begin{array}{l}\text { Maturity } \\
\text { CVM-400 }\end{array}$}} & \multicolumn{2}{|c|}{ Regular bonds } & \multicolumn{2}{|c|}{ Infra bonds } & \multirow{2}{*}{ Overall } \\
\hline & & CVM-476 & CVM-400 & CVM-476 & & \\
\hline$<3$ years & & $\begin{array}{l}10,3 \\
(29)\end{array}$ & $\begin{array}{l}86,4 \\
(549)\end{array}$ & - & - & $\begin{array}{c}14 \% \\
(22 \%)\end{array}$ \\
\hline 3 to 5 ye & & $\begin{array}{l}25,4 \\
(50)\end{array}$ & $\begin{array}{l}127,6 \\
(471)\end{array}$ & - & $\begin{array}{c}0,27 \\
(3)\end{array}$ & $\begin{array}{l}22 \% \\
(20 \%)\end{array}$ \\
\hline 5 to $10 y$ & & $\begin{array}{l}75,5 \\
(224)\end{array}$ & $\begin{array}{l}276,1 \\
(890)\end{array}$ & $\begin{array}{l}11,1 \\
(39)\end{array}$ & $\begin{array}{c}8,7 \\
(39)\end{array}$ & $\begin{array}{c}53 \% \\
(46 \%)\end{array}$ \\
\hline$>10$ year & & $\begin{array}{l}14,4 \\
(37)\end{array}$ & $\begin{array}{l}51,8 \\
(170)\end{array}$ & $\begin{array}{l}4,2 \\
(17)\end{array}$ & $\begin{array}{l}10,3 \\
(64)\end{array}$ & $\begin{array}{c}12 \% \\
(11 \%)\end{array}$ \\
\hline $\begin{array}{l}\text { Total } \\
(100 \%)\end{array}$ & $\begin{array}{l}\text { BRL bn } \\
\text { (\# issues) }\end{array}$ & $\begin{array}{l}66,8 \\
(166)\end{array}$ & $\begin{array}{c}542 \\
(2.088)\end{array}$ & $\begin{array}{l}15,5 \\
(56)\end{array}$ & $\begin{array}{l}19,3 \\
(106)\end{array}$ & $\begin{array}{c}643,6 \\
(2.408)\end{array}$ \\
\hline
\end{tabular}

Total in BRL billions, total number of issues (in parentheses), percentage of total in BRL billions, and percentage of total number of issues (in parentheses). Infra bonds: bonds issued to fund priority infrastructure projects (created by Law 12,431 of 2011); Common bonds: non-infra bonds; CVM-400: bonds issued under Instruction CVM-400 (registration required and broad distribution); and CVM-476: bonds issued under Instruction CVM-476 (registration not required and distribution restricted to a limited number of professional investors). Source: Brazilian Association of Capital Markets Participant (ANBIMA). Available at www.debentures.com.br. 
Fixed versus Linked yield (retorno pré- and pós-fixado, in Portuguese): In general, Brazilian bonds have linked yields. Table 4 reports the types of yields. Fixed-yield bonds account for only $2.3 \%$ of the aggregate proceeds $(0.8 \%$ of the number of issues). The vast majority of bonds, accounting for nearly $78 \%$ of the proceeds and number of issues, are linked to the Brazilian interbank offered rate ( $C D I$ or $D I$ ). Inflation-linked bonds account for
$11 \%$ of proceeds and $17 \%$ of issues. Inflationlinkage prevails among infra bonds (69\% of proceeds and $91 \%$ of the number of issues). Inflation-linkage is also frequent among regular CVM-400 bonds (28.5\% of proceeds and $36.7 \%$ of the number of issues). US dollar-linked bonds are rare, accounting for only $6.4 \%$ of proceeds and $0.3 \%$ of the number of issues. Thus, US dollarlinked issues are large ones.

Table 4

\section{Types of Yields}

\begin{tabular}{|c|c|c|c|c|c|}
\hline \multicolumn{6}{|c|}{ Sample period 2009-2017 } \\
\hline \multirow{2}{*}{$\begin{array}{l}\text { Index } \\
\text { CVM-400 }\end{array}$} & \multicolumn{2}{|c|}{ Regular bonds } & \multicolumn{2}{|c|}{ Infra bonds } & \multirow[t]{2}{*}{ Overall $(\%)$} \\
\hline & CVM-476 & CVM-400 & CVM-476 & & \\
\hline Fixed rate & $\begin{array}{c}2,3 \% \\
(1,8 \%)\end{array}$ & $\begin{array}{c}1,4 \% \\
(0,4 \%)\end{array}$ & - & $\begin{array}{l}28,1 \% \\
(7,5 \%)\end{array}$ & $\begin{array}{c}2,3 \% \\
(0,8 \%)\end{array}$ \\
\hline Interest rate (DI) & $\begin{array}{c}64,1 \% \\
(57,8 \%)\end{array}$ & $\begin{array}{c}84,1 \% \\
(87,1 \%)\end{array}$ & - & - & $\begin{array}{c}77,5 \% \\
(79,2 \%)\end{array}$ \\
\hline Inflation index (any one) & $\begin{array}{c}28,5 \% \\
(36,7 \%)\end{array}$ & $\begin{array}{c}4,4 \% \\
(9,2 \%)\end{array}$ & $\begin{array}{c}100 \% \\
(100 \%)\end{array}$ & $\begin{array}{c}69,7 \% \\
(91,5 \%)\end{array}$ & $\begin{array}{c}11,1 \% \\
(16,9 \%)\end{array}$ \\
\hline Government-arbitrated & $\begin{array}{c}3,1 \% \\
(2,4 \%)\end{array}$ & $\begin{array}{c}1,1 \% \\
(2,5 \%)\end{array}$ & - & $\begin{array}{c}2,2 \% \\
(0,9 \%)\end{array}$ & $\begin{array}{c}1,3 \% \\
(2,3 \%)\end{array}$ \\
\hline Dollar & - & $\begin{array}{l}7,6 \% \\
(0,4 \%)\end{array}$ & - & - & $\begin{array}{c}6,4 \% \\
(0,3 \%)\end{array}$ \\
\hline Other & $\begin{array}{c}1,9 \% \\
(1,2 \%)\end{array}$ & $\begin{array}{c}1,3 \% \\
(0,4 \%)\end{array}$ & - & - & $\begin{array}{c}1,3 \% \\
(0,4 \%)\end{array}$ \\
\hline $\begin{array}{l}\text { BRL bn } \\
\text { (\# issues) }\end{array}$ & $\begin{array}{c}66,8 \\
(166)\end{array}$ & $\begin{array}{c}542 \\
(2.088)\end{array}$ & $\begin{array}{l}15,5 \\
(56)\end{array}$ & $\begin{array}{c}19,3 \\
(106)\end{array}$ & $\begin{array}{c}643,6 \\
(2.408)\end{array}$ \\
\hline
\end{tabular}

Proceeds: Proceeds are relatively low. Only $13.5 \%$ of the issues have proceeds of more than BRL 500 million. However, the aggregate proceeds of such bonds correspond to $54.2 \%$ of the total (Table 5, last column). On the other hand, small issues (proceeds of below BRL 100 million) represent only $6.5 \%$ of aggregate proceeds, but this corresponds to $38 \%$ of the number of issues. CVM-476 seems to be most frequently used for small issues: $40.1 \%$ of issues have proceeds of below BRL 100 million, but this corresponds to only $6.9 \%$ of proceeds. This characteristic is relatively uniform across all types of bonds. 
Table 5

Issue Size

\begin{tabular}{|c|c|c|c|c|c|c|}
\hline \multicolumn{7}{|c|}{ Período amostral: 2009-2017 } \\
\hline \multirow{2}{*}{$\begin{array}{l}\text { BRL m } \\
\text { CVM-400 }\end{array}$} & & \multicolumn{2}{|c|}{ Regular bonds } & \multicolumn{2}{|c|}{ Infra bonds } & \multirow[t]{2}{*}{ Overall } \\
\hline & & CVM-476 & CVM-400 & CVM-476 & & \\
\hline$<100$ & & $\begin{array}{c}2,6 \% \\
(16,3 \%)\end{array}$ & $\begin{array}{c}6,9 \% \\
(40,1 \%)\end{array}$ & $\begin{array}{c}4,5 \% \\
(19,6 \%)\end{array}$ & $\begin{array}{c}12,2 \% \\
(41,5 \%)\end{array}$ & $\begin{array}{c}6,5 \% \\
(38,0 \%)\end{array}$ \\
\hline 100 a 250 & & $\begin{array}{c}11,2 \% \\
(27,7 \%)\end{array}$ & $\begin{array}{c}18,0 \% \\
(31,2 \%)\end{array}$ & $\begin{array}{c}21,8 \% \\
(35,7 \%)\end{array}$ & $\begin{array}{c}31,9 \% \\
(38,7 \%)\end{array}$ & $\begin{array}{c}17,8 \% \\
(31,4 \%)\end{array}$ \\
\hline 250 a 500 & & $\begin{array}{c}25,6 \% \\
(29,5 \%)\end{array}$ & $\begin{array}{c}20,4 \% \\
(15,8 \%)\end{array}$ & $\begin{array}{c}34,1 \% \\
(28,6 \%)\end{array}$ & $\begin{array}{c}28,3 \% \\
(15,1 \%)\end{array}$ & $\begin{array}{c}21,5 \% \\
(17,0 \%)\end{array}$ \\
\hline$>500$ & & $\begin{array}{c}60,5 \% \\
(26,5 \%)\end{array}$ & $\begin{array}{c}54,8 \% \\
(12,9 \%)\end{array}$ & $\begin{array}{c}39,6 \% \\
(16,1 \%)\end{array}$ & $\begin{array}{l}27,7 \% \\
(4,7 \%)\end{array}$ & $\begin{array}{c}54,2 \% \\
(13,5 \%)\end{array}$ \\
\hline Total & $\begin{array}{l}\text { BRL bn } \\
\text { (\# issues) }\end{array}$ & $\begin{array}{l}66,8 \\
(166)\end{array}$ & $\begin{array}{c}542 \\
(2.088)\end{array}$ & $\begin{array}{l}15,5 \\
(56)\end{array}$ & $\begin{array}{l}19,3 \\
(106)\end{array}$ & $\begin{array}{c}643,6 \\
(2.408)\end{array}$ \\
\hline
\end{tabular}

Total in BRL billions, total number of issues (in parentheses), percentage of total amount in BRL billions, and percentage of total number of issues (in parentheses). Infra bonds: bonds issued to fund priority infrastructure projects (created by Law 12,431 of 2011); Regular bonds: non-infra bonds; CVM-400: bonds issued under Instruction CVM-400 (registration required and broad distribution); and CVM-476: bonds issued under Instruction CVM-476 (registration not required and distribution restricted to a limited number of professional investors). Source: Brazilian Association of Capital Market Participants (ANBIMA). Available at www.debentures.com.br.

Underwriting: Unlike other bond markets, where the underwriting of bonds is usually competitive and dominated by international investment banks (Carbo-Valverde, RodriguezFernandez, \& Saunders, 2016; Manconi, Neretina, \& Renneboog, 2018), underwriting in the Brazilian bond market is dominated by only two local universal banks. Table 6 reports on underwriting in the Brazilian bond market. Bradesco has the largest share: $53.3 \%$ of proceeds and $49.6 \%$ of issues. Itau-Unibanco has $43.5 \%$ of proceeds and $45.5 \%$ of issues. Banco do Brasil comes next with only $0.8 \%$ of proceeds and $0.4 \%$ of issues. This pattern is consistent across regular and infra bonds, and CVM-400 and CVM-476 issues. 
Table 6

Leading Underwriters

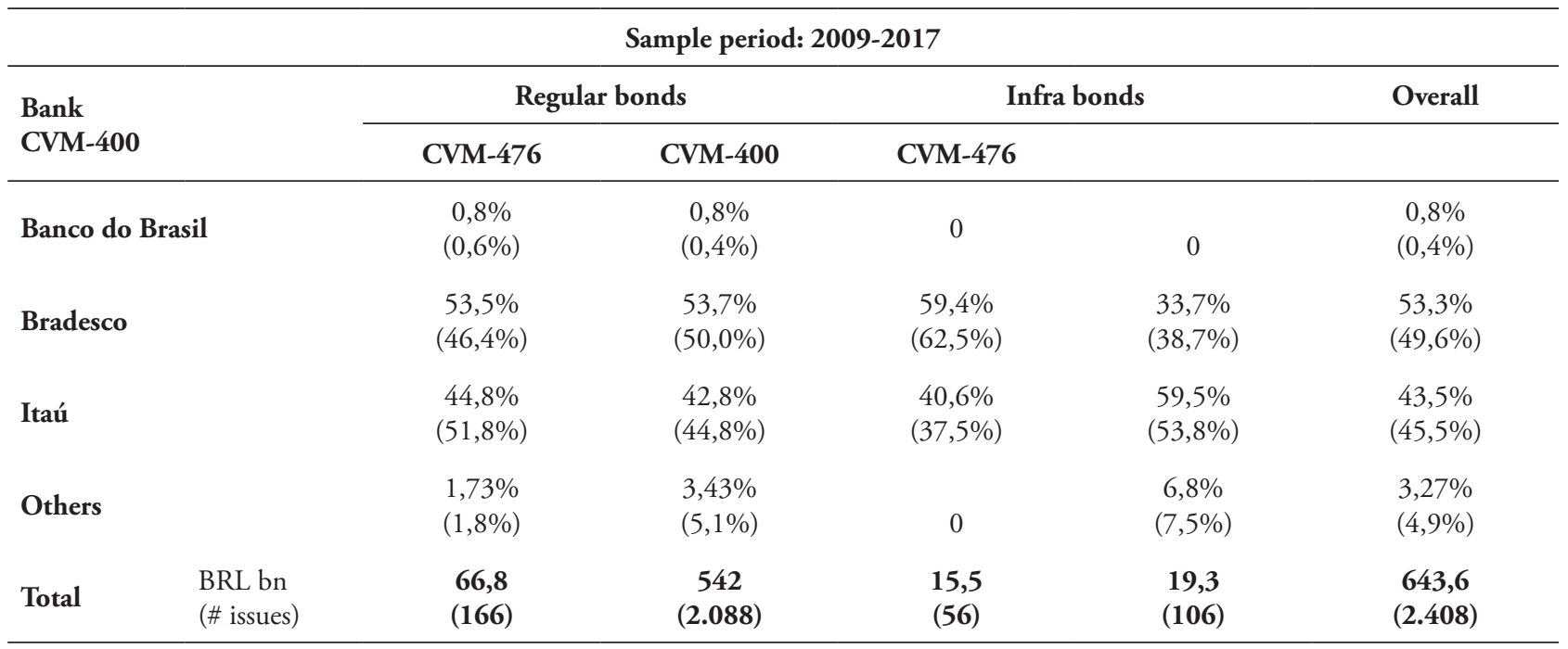

Total in BRL billions, total number of issues (in parentheses), percentage of total amount in BRL billions, and percentage of total number of issues (in parentheses). Infra bonds: bonds issued to fund priority infrastructure projects (created by Law 12,431 of 2011); Regular bonds: non-infra bonds; CVM-400: bonds issued under Instruction CVM-400 (registration required and broad distribution); and CVM-476: bonds issued under Instruction CVM-476 (registration not required and distribution restricted to a limited number of professional investors). Source: Brazilian Association of Capital Market Participants (ANBIMA). Available at www.debentures.com.br.

\subsection{Ex-ante issuer performance}

Ratings: Brazilian bond ratings come predominantly from global rating agencies (Standard and Poors - S\&P, Moodys, and Fitch). However, ratings also come from local rating agencies (mainly LF Rating and Austin Rating). Global rating agencies use a local rating scale, corresponding to their global scale with the suffix or prefix $\mathrm{BR}$ to indicate a local rating. For instance, S\&P's best rating for Brazilian bonds is brAAA, which bears the same risk as Brazilian sovereign bonds (thus, brAAA is not equivalent to the global
AAA). The reference for local investment grade is the same as for the global one. For instance, S\&P's lowest local investment-grade rating is brBBB-.

Table 7 reports on ratings. It is remarkable that more than half of the issues, accounting for $55.9 \%$ of the proceeds and $61.3 \%$ of the number of issues, have no rating at all. Issues with no rating prevail almost exclusively among regular CVM-476 bonds: $66 \%$ of proceeds and $70.5 \%$ of issues. Infra bonds usually have an investment grade: less than $10 \%$ of the infra bonds do not have an investment grade. 
Table 7

Bond Issuance by Rating

\begin{tabular}{|c|c|c|c|c|c|c|}
\hline \multicolumn{7}{|c|}{ Sample period 2009-2017 } \\
\hline \multirow{2}{*}{\multicolumn{2}{|c|}{$\begin{array}{l}\text { Percent } \\
\text { CVM-400 }\end{array}$}} & \multicolumn{2}{|c|}{ Regular bonds } & \multicolumn{2}{|c|}{ Infra bonds } & \multirow{2}{*}{ Overall $(\%)$} \\
\hline & & CVM-476 & CVM-400 & CVM-476 & & \\
\hline \multicolumn{2}{|c|}{ Investment grade } & $\begin{array}{c}97,6 \% \\
(98,2 \%)\end{array}$ & $\begin{array}{c}33,6 \% \\
(28,2 \%)\end{array}$ & $100 \%$ & $\begin{array}{c}94,2 \% \\
(91,5 \%)\end{array}$ & $\begin{array}{c}43,6 \% \\
(37,5 \%)\end{array}$ \\
\hline \multicolumn{2}{|c|}{ Non-investment grade } & $\begin{array}{c}0,9 \% \\
(1,2 \%)\end{array}$ & $\begin{array}{c}0,5 \% \\
(1,3 \%)\end{array}$ & - & - & $\begin{array}{c}0,5 \% \\
(1,2 \%)\end{array}$ \\
\hline \multicolumn{2}{|c|}{ Not rated } & $\begin{array}{c}1,5 \% \\
(0,6 \%)\end{array}$ & $\begin{array}{c}66,0 \% \\
(70,5 \%)\end{array}$ & - & $\begin{array}{c}5,8 \% \\
(8,5 \%)\end{array}$ & $\begin{array}{c}55,9 \% \\
(61,3 \%)\end{array}$ \\
\hline Total & $\begin{array}{l}\text { BRL bn } \\
\text { (\# issues) }\end{array}$ & $\begin{array}{c}66,8 \\
(166)\end{array}$ & $\begin{array}{c}542 \\
(2.088)\end{array}$ & $\begin{array}{l}15,5 \\
(56)\end{array}$ & $\begin{array}{c}19,3 \\
(106)\end{array}$ & $\begin{array}{c}643,6 \\
(2.408)\end{array}$ \\
\hline
\end{tabular}

Total in BRL billions, total number of issues (in parentheses), percentage of total amount in BRL billions, and percentage of the total number of issues (in parentheses). Infra bonds: bonds issued to fund priority infrastructure projects (created by Law 12,431 of 2011); Regular bonds: non-infra bonds; CVM-400: bonds issued under Instruction CVM-400 (registration required and broad distribution); and CVM-476: bonds issued under Instruction CVM-476 (registration not required and distribution restricted to a limited number of professional investors). Source: Brazilian Association of Capital Market Agents (ANBIMA). Available at www.debentures.com.br.

Ex-ante credit events (EACEs: defaults or renegotiations): As an indicator of bond quality, reported EACEs complement ratings. Table 8 shows EACEs for two separate periods: 2009-2013 and 2014-2017. CVM-400 was predominant in the first period, and CVM-476 in the second (we exclude issues before 2009, when there was no CVM-476). Strikingly, the frequency of EACEs is high, regardless of the period. Overall, EACEs were reported for nearly $25 \%$ of proceeds, representing 23 to $30 \%$ of the number of issues. EACEs are significantly more frequent for CVM476 than for CVM-400 bonds, and for regular rather than for infra bonds. Focusing on regular bonds in the second period, the EACE rate was higher for CVM-476 than for CVM-400 bonds: $26.8 \%$ versus $17.6 \%$ of the proceeds. Reported EACEs were still frequent among infra bonds (6.3\% for CVM-400 and $11.7 \%$ for CVM-476). 
Table 8

Ex-ante Credit Events (EACEs)

\begin{tabular}{|c|c|c|c|c|c|c|}
\hline \multicolumn{7}{|c|}{ Panel A: Sample period 2009-2013 } \\
\hline \multirow{2}{*}{ CVM-400 } & & \multicolumn{2}{|c|}{ Regular bonds } & \multicolumn{2}{|c|}{ Infra bonds } & \multirow{2}{*}{ Overall } \\
\hline & & CVM-476 & CVM-400 & CVM-476 & & \\
\hline EACEs & & $\begin{array}{c}21,1 \% \\
(20,4 \%)\end{array}$ & $\begin{array}{c}27,8 \% \\
(24,4 \%)\end{array}$ & - & $\begin{array}{c}8,4 \% \\
(16,7 \%)\end{array}$ & $\begin{array}{c}25,8 \% \\
(23,5 \%)\end{array}$ \\
\hline No EACEs & & $\begin{array}{c}78,9 \% \\
(79,6 \%)\end{array}$ & $\begin{array}{c}72,2 \% \\
(75,6 \%)\end{array}$ & $100 \%$ & $\begin{array}{c}91,6 \% \\
(83,3 \%)\end{array}$ & $\begin{array}{c}74,2 \% \\
(76,5 \%)\end{array}$ \\
\hline Total & $\begin{array}{l}\text { BRL bn } \\
\text { (\# issues) }\end{array}$ & $\begin{array}{c}54,4 \\
(147) \\
\end{array}$ & $\begin{array}{c}234,4 \\
(1.009) \\
\end{array}$ & $\begin{array}{l}3,9 \\
(13)\end{array}$ & $\begin{array}{c}6,4 \\
(18) \\
\end{array}$ & $\begin{array}{c}299,2 \\
(1.187) \\
\end{array}$ \\
\hline \multicolumn{7}{|c|}{ Panel B: Sample period: 2014-2017 } \\
\hline \multirow{2}{*}{ CVM-400 } & & \multicolumn{2}{|c|}{ Regular bonds } & \multicolumn{2}{|c|}{ Infra bonds } & O-all \\
\hline & & CVM-476 & CVM-400 & CVM-476 & & Uverall \\
\hline EACEs & & $\begin{array}{c}17,6 \% \\
(26,3 \%)\end{array}$ & $\begin{array}{c}26,8 \% \\
(33,4 \%)\end{array}$ & $\begin{array}{c}6,3 \% \\
(7,0 \%)\end{array}$ & $\begin{array}{l}11,7 \% \\
(9,1 \%)\end{array}$ & $\begin{array}{c}25,2 \% \\
(30,6 \%)\end{array}$ \\
\hline No EACEs & & $\begin{array}{c}82,4 \% \\
(73,7 \%)\end{array}$ & $\begin{array}{c}73,2 \% \\
(66,6 \%)\end{array}$ & $\begin{array}{c}93,7 \% \\
(93,0 \%)\end{array}$ & $\begin{array}{c}88,3 \% \\
(90,9 \%)\end{array}$ & $\begin{array}{c}74,8 \% \\
(69,4 \%)\end{array}$ \\
\hline Total & $\begin{array}{l}\text { BRL bn } \\
\text { (\# issues) }\end{array}$ & $\begin{array}{l}12,3 \\
(19)\end{array}$ & $\begin{array}{c}307,6 \\
(1.071)\end{array}$ & $\begin{array}{l}11,6 \\
(43)\end{array}$ & $\begin{array}{l}13,0 \\
(88)\end{array}$ & $\begin{array}{c}344,4 \\
(1.221)\end{array}$ \\
\hline
\end{tabular}

Ex-ante Credit Events (renegotiations and defaults). Total in BRL billions, total number of issues (in parentheses), percentage of total amount in BRL billions, and percentage of the total number of issues (in parentheses). Infra bonds: bonds issued to fund priority infrastructure projects (created by Law 12,431 of 2011); Regular bonds: non-infra bonds; CVM-400: bonds issued under Instruction CVM-400 (registration required and broad distribution); and CVM-476: bonds issued under Instruction CVM-476 (registration not required and distribution restricted to a limited number of professional investors). Source: Brazilian Association of Capital Market Participants (ANBIMA). Available at www.debentures.com.br.

To further investigate ex-ante credit events, Table 9 splits them into strict defaults and renegotiations. The sample period is 2014-2017. By considering a more recent sample period, we increase the issuers' EACE track record. Panel A shows that renegotiation was quite frequent, affecting $23.4 \%$ of the proceeds and $29.0 \%$ of the issues. This is surprising, given the efforts and coordination involved in the negotiation of bond terms. As expected, the overall strict default rate is low (Panel B): $2.7 \%$ of the aggregate proceeds and $2.4 \%$ of the issues. Strict default occurs only among regular CVM-467 bonds $(2.9 \%$ of aggregate proceeds and $2.6 \%$ of issues) and infra CVM-400 bonds (4.0\% of aggregate proceeds and $2.3 \%$ of issues). 
Table 9

Ex-ante Credit Events (EACEs): Renegotiations versus Strict Defaults

\begin{tabular}{|c|c|c|c|c|c|c|}
\hline \multicolumn{7}{|c|}{ Sample period: $2014-2017$} \\
\hline \multicolumn{7}{|c|}{ Panel A: Renegotiation } \\
\hline \multirow{2}{*}{\multicolumn{2}{|c|}{ CVM-400 }} & \multicolumn{2}{|c|}{ Regular bonds } & \multicolumn{2}{|c|}{ Infra bonds } & \multirow{2}{*}{ Overall } \\
\hline & & CVM-476 & CVM-400 & CVM-476 & & \\
\hline \multicolumn{2}{|c|}{ Renegotiations } & $\begin{array}{c}17,6 \% \\
(26,3 \%)\end{array}$ & $\begin{array}{c}24,9 \% \\
(31,7 \%)\end{array}$ & $\begin{array}{c}2,3 \% \\
(4,7 \%)\end{array}$ & $\begin{array}{l}11,7 \% \\
(9,1 \%)\end{array}$ & $\begin{array}{c}23,4 \% \\
(29,0 \%)\end{array}$ \\
\hline \multicolumn{2}{|c|}{ No renegotiations } & $\begin{array}{c}82,4 \% \\
(73,7 \%)\end{array}$ & $\begin{array}{c}75,1 \% \\
(68,3 \%)\end{array}$ & $\begin{array}{c}97,7 \% \\
(95,3 \%)\end{array}$ & $\begin{array}{c}88,3 \% \\
(90,9 \%)\end{array}$ & $\begin{array}{c}76,6 \% \\
(71,0 \%)\end{array}$ \\
\hline Total & $\begin{array}{l}\text { BRL bn } \\
\text { (\# issues) }\end{array}$ & $\begin{array}{l}12,3 \\
(19) \\
\end{array}$ & $\begin{array}{c}307,6 \\
(1.071) \\
\end{array}$ & $\begin{array}{l}11,6 \\
(43)\end{array}$ & $\begin{array}{l}13,0 \\
(88) \\
\end{array}$ & $\begin{array}{c}344,4 \\
(1.221) \\
\end{array}$ \\
\hline \multicolumn{7}{|c|}{ Panel B: Strict Default } \\
\hline \multirow{2}{*}{\multicolumn{2}{|c|}{ CVM-400 }} & \multicolumn{2}{|c|}{ Regular bonds } & \multicolumn{2}{|c|}{ Infra bonds } & \multirow{2}{*}{ Overall } \\
\hline & & CVM-476 & CVM-400 & CVM-476 & & \\
\hline \multicolumn{2}{|c|}{ Strict defaults } & - & $\begin{array}{c}2,9 \% \\
(2,6 \%)\end{array}$ & $\begin{array}{c}4,0 \% \\
(2,3 \%)\end{array}$ & - & $\begin{array}{c}2,7 \% \\
(2,4 \%)\end{array}$ \\
\hline \multicolumn{2}{|c|}{ No defaults } & $100 \%$ & $\begin{array}{c}97,1 \% \\
(97,4 \%)\end{array}$ & $\begin{array}{c}96,0 \% \\
(97,7 \%)\end{array}$ & $100 \%$ & $\begin{array}{c}97,3 \% \\
(97,6 \%)\end{array}$ \\
\hline Total & $\begin{array}{l}\text { BRL bn } \\
\text { (\# issues) }\end{array}$ & $\begin{array}{l}12,3 \\
(19)\end{array}$ & $\begin{array}{c}307,6 \\
(1.071)\end{array}$ & $\begin{array}{l}11,6 \\
(43)\end{array}$ & $\begin{array}{l}13,0 \\
(88)\end{array}$ & $\begin{array}{c}344,4 \\
(1.221)\end{array}$ \\
\hline
\end{tabular}

Total in BRL billions, total number of issues (in parentheses), percentage of total amount in BRL billions, and percentage of the total number of issues (in parentheses). Infra bonds: bonds issued to fund priority infrastructure projects (created by Law 12,431 of 2011); Regular bonds: non-infra bonds; CVM-400: bonds issued under Instruction CVM-400 (registration required and broad distribution); and CVM-476: bonds issued under Instruction CVM-476 (registration not required and distribution restricted to a limited number of professional investors). Source: Brazilian Association of Capital Market Participants (ANBIMA). Available at www.debentures.com.br.

One would expect a negative correlation between EACEs and investment grades. In particular, issuers that receive investment grades are not expected to have reported EACEs. We investigate this. Table 10 reports a cross-tabulation between investment grades and EACEs in the 2014-2017 period. As expected, the EACE rate is lower among investment grade bonds than among bonds with no investment grade or without any rating: $20.0 \%$ versus $55.5 \%$ and $34.1 \%$ of issues in each category, respectively. Strikingly, 20\% (63 of 315 issues) is a very high rate of EACEs for investment grade bonds. However, only 3 of these 63 issues $(0.9 \%)$ were from issuers that had reported a strict default. Thus, surprisingly, it seems that ratings do not reflect renegotiation as a credit event. 
Table 10

Bond Ratings versus Ex-ante Credit Events (EACEs)

\begin{tabular}{|c|c|c|c|c|}
\hline \multicolumn{5}{|c|}{ (sample period 2009-2013) } \\
\hline \multirow{2}{*}{ Number of issues } & \multirow{2}{*}{ No EACEs } & \multirow{2}{*}{ EACEs } & \multicolumn{2}{|c|}{ EACEs } \\
\hline & & & Renegotiations & Strict Defaults \\
\hline Investment grade & $\begin{array}{c}252 \\
(80 \%)\end{array}$ & $\begin{array}{c}63 \\
(20,0 \%)\end{array}$ & $\begin{array}{c}60 \\
(19,0 \%)\end{array}$ & $\begin{array}{c}3 \\
(0,9 \%)\end{array}$ \\
\hline Non-investment grade & $\begin{array}{c}4 \\
(45,5 \%)\end{array}$ & $\begin{array}{c}5 \\
(55,5 \%)\end{array}$ & $\begin{array}{c}5 \\
(55,5 \%)\end{array}$ & $\begin{array}{c}2 \\
(22,2 \%)\end{array}$ \\
\hline Not rated & $\begin{array}{c}591 \\
(65,9 \%)\end{array}$ & $\begin{array}{c}306 \\
(34,1 \%)\end{array}$ & $\begin{array}{c}289 \\
(32,2 \%)\end{array}$ & $\begin{array}{c}24 \\
(2,6)\end{array}$ \\
\hline
\end{tabular}

Number of issues and the percentage of the total number of issues (in parentheses). Investment grade: bonds with credit rating equal to or higher than BBB-, on the Brazilian local scale. Non-investment grade: bonds with credit rating lower than BBB-. Not rated: bonds issued without credit rating. Ex-Ante Credit Events (EACEs): existence of previous events involving renegotiation or strict default by the issuer before the issuance. Source: Brazilian Association of Capital Market Agents (ANBIMA). Available at www.debentures.com.br.

\subsection{Ex-post bond performance}

Ex-post credit events (EPCEs: either defaults or renegotiations). The main indicator for bond performance is the occurrence of EPCEs. Table 11 reports on EPCEs for two separate periods: 20092013 and 2014-2017. One would expect the frequency of EPCEs to be lower in the more recent period, because the sample includes recently issued bonds. However, overall EPCEs are very similar in both periods: nearly $20 \%$ of proceeds and the number of issues. The unexpectedly high frequency of EPCEs in the second period comes mostly from regular CVM-476 bonds, which represent $89 \%$ of proceeds in the period
(307.6/344.4). Thus, regular CVM-476 bonds begin to present credit events from quite an early period after their issuance. For the other types of bonds, the result is as expected: a very low rate of EPCEs in the recent period. Also surprisingly, the rate of EPCEs among infra bonds in the first period is very high: $34.8 \%$ of proceeds among CVM-400 bonds and 45.9\% among CVM-476 bonds. These high values are driven by two factors: the small size of the infra-bond market and the EPCEs of a few issuers ( 2 issues from OAS and OGX, which filed for financial distress, and four other issues from Termeletrica Pernambuco). 
Table 11

Ex-post Credit Events (EPCEs)

\begin{tabular}{|c|c|c|c|c|c|c|}
\hline \multicolumn{7}{|c|}{ Panel A: Sample period 2009-2013 } \\
\hline \multirow{2}{*}{ CVM-400 } & & \multicolumn{2}{|c|}{ Regular bonds } & \multicolumn{2}{|c|}{ Infra bonds } & \multirow{2}{*}{ Overall } \\
\hline & & CVM-476 & CVM-400 & CVM-476 & & \\
\hline EPCEs & & $\begin{array}{l}9,8 \% \\
(8,8 \%)\end{array}$ & $\begin{array}{c}20,3 \% \\
(22,4 \%)\end{array}$ & $\begin{array}{c}34,8 \% \\
(38,5 \%)\end{array}$ & $\begin{array}{c}45,9 \% \\
(33,3 \%)\end{array}$ & $\begin{array}{c}19,1 \% \\
(21,1 \%)\end{array}$ \\
\hline No EPCEs & & $\begin{array}{c}90,2 \% \\
(91,2 \%)\end{array}$ & $\begin{array}{l}79,7 \% \\
(77,6 \%)\end{array}$ & $\begin{array}{c}65,2 \% \\
(61,5 \%)\end{array}$ & $\begin{array}{c}54,1 \% \\
(66,7 \%)\end{array}$ & $\begin{array}{c}80,9 \% \\
(78,9 \%)\end{array}$ \\
\hline Total & $\begin{array}{l}\text { BRL bn } \\
\text { (\# issues) }\end{array}$ & $\begin{array}{l}54,4 \\
(147) \\
\end{array}$ & $\begin{array}{c}234,4 \\
(1.009) \\
\end{array}$ & $\begin{array}{r}3,9 \\
(13) \\
\end{array}$ & $\begin{array}{r}6,4 \\
(18) \\
\end{array}$ & $\begin{array}{r}299,2 \\
(1.187) \\
\end{array}$ \\
\hline \multicolumn{7}{|c|}{ Panel B: Sample period 2014-2017 } \\
\hline \multirow{2}{*}{ CVM-400 } & & \multicolumn{2}{|c|}{ Regular bonds } & \multirow{2}{*}{\multicolumn{2}{|c|}{$\begin{array}{l}\text { Infra bonds } \\
\text { CVM-476 }\end{array}$}} & Overall \\
\hline & & CVM-476 & CVM-400 & & & Uverall \\
\hline EPCEs & & $\begin{array}{c}2,2 \% \\
(5,3 \%)\end{array}$ & $\begin{array}{c}23,0 \% \\
(25,0 \%)\end{array}$ & $\begin{array}{l}2,6 \% \\
(2,3 \%)\end{array}$ & $\begin{array}{c}2,5 \% \\
(2,3 \%)\end{array}$ & $\begin{array}{c}20,8 \% \\
(22,3 \%)\end{array}$ \\
\hline No EPCEs & & $\begin{array}{l}97,8 \% \\
(94,7 \%)\end{array}$ & $\begin{array}{l}77,0 \% \\
(75,0 \%)\end{array}$ & $\begin{array}{c}97,4 \% \\
(97,7 \%)\end{array}$ & $\begin{array}{l}97,5 \% \\
(97,7 \%)\end{array}$ & $\begin{array}{l}79,2 \% \\
(77,7 \%)\end{array}$ \\
\hline Total & $\begin{array}{l}\text { BRL bn } \\
\text { (\# issues) }\end{array}$ & $\begin{array}{l}12,3 \\
(19)\end{array}$ & $\begin{array}{c}307,6 \\
(1.071)\end{array}$ & $\begin{array}{l}11,6 \\
(43)\end{array}$ & $\begin{array}{l}13,0 \\
(88)\end{array}$ & $\begin{array}{c}344,4 \\
(1.221)\end{array}$ \\
\hline
\end{tabular}

EPCEs: defaults and renegotiations. Total in BRL billions, total number of issues (in parentheses), percentage of total amount in BRL billions, and percentage of total number of issues (in parentheses). Infra-bonds: bonds issued to fund priority infrastructure projects (created by Law 12,431 of 2011); Regular bonds: non-infra bonds; CVM-400: bonds issued under Instruction CVM-400 (registration required and broad distribution); and CVM-476: bonds issued under Instruction CVM-476 (registration not required and distribution restricted to a limited number of professional investors). Source: Brazilian Association of Capital Market Participants (ANBIMA). Available at www.debentures.com.br.

To further investigate ex-post credit events, Table 12 splits them into strict defaults and renegotiations. The sample period is 20092013. Panel A shows that renegotiations were quite frequent, affecting $16.4 \%$ of proceeds and $17.20 \%$ of issues. As expected, the overall strict default rate is smaller, but still considerable (Panel
B): $6.2 \%$ of aggregate proceeds and $8.7 \%$ of issues. Since the EPCEs among infra bonds are biased by a few cases, we focus only on regular bonds. Strict default occurs mostly among regular CVM-467 bonds (5.7\% of proceeds and 8.8\% of issues). 
Table 12

Ex-post Credit Events (EPCEs): Renegotiations versus Defaults

\begin{tabular}{|c|c|c|c|c|c|c|}
\hline \multicolumn{7}{|c|}{ Sample period: $2009-2013$} \\
\hline \multicolumn{7}{|c|}{ Panel A: Renegotiation } \\
\hline \multirow{2}{*}{\multicolumn{2}{|c|}{ CVM-400 }} & \multicolumn{2}{|c|}{ Regular bonds } & \multicolumn{2}{|c|}{ Infra bonds } & \multirow{2}{*}{ Overall } \\
\hline & & CVM-476 & CVM-400 & CVM-476 & & \\
\hline \multicolumn{2}{|c|}{ Renegotiations } & $\begin{array}{c}8,8 \% \\
(7,5 \%)\end{array}$ & $\begin{array}{c}18,3 \% \\
(18,5 \%)\end{array}$ & $\begin{array}{c}32,9 \% \\
(30,8 \%)\end{array}$ & $\begin{array}{c}1,6 \% \\
(11,1 \%)\end{array}$ & $\begin{array}{c}16,4 \% \\
(17,2 \%)\end{array}$ \\
\hline \multicolumn{2}{|c|}{ No-renegotiations } & $\begin{array}{c}91,2 \% \\
(92,5 \%)\end{array}$ & $\begin{array}{c}81,7 \% \\
(81,5 \%)\end{array}$ & $\begin{array}{c}67,1 \% \\
(69,2 \%)\end{array}$ & $\begin{array}{l}98,4 \% \\
(88,9 \%)\end{array}$ & $\begin{array}{c}83,6 \% \\
(82,8 \%)\end{array}$ \\
\hline Total & $\begin{array}{l}\text { BRL bn } \\
\text { (\# issues) }\end{array}$ & $\begin{array}{l}54,4 \\
(147)\end{array}$ & $\begin{array}{c}234,4 \\
(1.009)\end{array}$ & $\begin{array}{r}3,9 \\
(13)\end{array}$ & $\begin{array}{c}6,4 \\
(18)\end{array}$ & $\begin{array}{c}299,2 \\
(1.187)\end{array}$ \\
\hline \multicolumn{7}{|c|}{ Panel B: Strict Default } \\
\hline \multirow{2}{*}{\multicolumn{2}{|c|}{ CVM-400 }} & \multicolumn{2}{|c|}{ Regular bonds } & \multirow{2}{*}{\multicolumn{2}{|c|}{$\begin{array}{r}\text { Infra bonds } \\
\text { CVM-476 }\end{array}$}} & \multirow{2}{*}{ Overall } \\
\hline & & CVM-476 & CVM-400 & & & \\
\hline \multicolumn{2}{|c|}{ Strict Defaults } & $\begin{array}{c}1,7 \% \\
(2,0 \%)\end{array}$ & $\begin{array}{c}5,7 \% \\
(8,8 \%)\end{array}$ & $\begin{array}{c}34,8 \% \\
(38,5 \%)\end{array}$ & $\begin{array}{c}45,9 \% \\
(33,3 \%)\end{array}$ & $\begin{array}{c}6,2 \% \\
(8,7 \%)\end{array}$ \\
\hline \multicolumn{2}{|c|}{ No-Defaults } & $\begin{array}{l}93,8 \% \\
(98,0 \%)\end{array}$ & $\begin{array}{l}94,3 \% \\
(91,2 \%)\end{array}$ & $\begin{array}{c}65,2 \% \\
(61,5 \%)\end{array}$ & $\begin{array}{l}54,1 \% \\
(66,7 \%)\end{array}$ & $\begin{array}{c}93,8 \% \\
(91,3 \%)\end{array}$ \\
\hline Total & $\begin{array}{l}\text { BRL bn } \\
\text { (\# issues) }\end{array}$ & $\begin{array}{l}54,4 \\
(147)\end{array}$ & $\begin{array}{c}234,4 \\
(1.009)\end{array}$ & $\begin{array}{r}3,9 \\
(13)\end{array}$ & $\begin{array}{c}6,4 \\
(18)\end{array}$ & $\begin{array}{c}299,2 \\
(1.187)\end{array}$ \\
\hline
\end{tabular}

Total in BRL billions, total number of issues (in parentheses), percentage of total amount in BRL billions, and percentage of total number of issues (in parentheses). Infra bonds: bonds issued to fund priority infrastructure projects (created by Law 12,431 of 2011); Regular bonds: non-infra bonds; CVM-400: bonds issued under Instruction CVM-400 (registration required and broad distribution); and CVM-476: bonds issued under Instruction CVM-476 (registration not required and distribution restricted to a limited number of professional investors). Source: Brazilian Association of Capital Market Participants (ANBIMA). Available at www.debentures.com.br.

Table 13 reports a cross-tabulation between investment grade and EPCEs in the 2009-2013 period. As expect, the EPCE rate is lower among investment-grade bonds than among non-investment grade ones (bonds bearing a non-investment rating or not rated): $11.2 \%$ versus $77.2 \%$ and $28.8 \%$ of issues in each category, respectively. This proportion, 11.2\% (66 of 586 issues), is a very high rate of EPCEs for investment-grade bonds. However, only 3.9\% (23 of 586 issues) resulted from strict defaults (most of the EPCEs are renegotiations). Nonetheless, this seems to be a very high default rate. For a comparison, consider the S\&P default rate for global investment-grade corporate bonds for the 1981-2016 period (Standard and Poors, 2017). The average EPCE (default rate) rate among $\mathrm{BBB}^{-}$bonds (the lowest investment grade) is only $0.26 \%$; among $\mathrm{B}^{-}$bonds, it is $9.6 \%$; and for junk bonds with ratings below CCC, it is $23.9 \%$ (recall that in Brazil, the default rate among noninvestment grade bonds is $77.2 \%$ ). 
Table 13

Bond Ratings versus Ex-post Credit Events (EPCEs)

\begin{tabular}{lcccc}
\hline & \multicolumn{2}{c}{ Sample period: 2009-2013 } & & EPCEs \\
Number of issues & No EPCEs & EPCEs & Renegotiations & Strict Defaults \\
Investment grade & 520 & 66 & 50 & 23 \\
Non-investment grade & $(88,8 \%)$ & $(11,2 \%)$ & $(8,5 \%)$ & $(3,9 \%)$ \\
& 5 & 17 & 15 & 4 \\
Not rated & $(22,8 \%)$ & $(77,2 \%)$ & $(68,2 \%)$ & $(18,2 \%)$ \\
& 412 & 167 & 139 & 76 \\
\hline
\end{tabular}

Number of issues and their percentage of the total number of issues (in parentheses). Investment grade: bonds issued with a credit rating equal to or higher than BBB- on the Brazilian local scale; Non-investment grade: bonds issued with a credit rating lower than $\mathrm{BBB}$ - on the Brazilian local scale; Not rated: bonds issued without a credit rating; Ex-Post Credit Events (EPCEs): events involving renegotiations or defaults after the issuance. Source: Brazilian Association of Capital Market Agents (ANBIMA). Available at www.debentures.com.br.

Liquidity: Our measure of liquidity is the percentage of days for which there was some trading of the bond. Table 14 reports the liquidity for bonds issued before 2013. 51.7\% of issues (38.2\% of proceeds) are never traded. Another $38.6 \%$ are traded on, at most, $5 \%$ of the days.
Only $1.5 \%$ of the issues are traded on more than $20 \%$ of the days. Liquidity varies across bond types. There is very little trading of regular CVM476 bonds: $58.8 \%$ of these issues are never traded. This is expected, considering that these issues are allocated to, at most, 50 investors.

Table 14

Bond Liquidity

\begin{tabular}{|c|c|c|c|c|c|c|}
\hline \multicolumn{7}{|c|}{ Sample period 2009-2013 } \\
\hline \multirow{2}{*}{\multicolumn{2}{|c|}{ CVM-400 }} & \multicolumn{2}{|c|}{ Regular bonds } & \multicolumn{2}{|c|}{ Infra bonds } & \multirow[t]{2}{*}{ Overall } \\
\hline & & CVM-476 & CVM-400 & CVM-476 & & \\
\hline $\mathbf{x}=\mathbf{0} \%$ & & $\begin{array}{c}7,2 \% \\
(8,8 \%)\end{array}$ & $\begin{array}{c}45,4 \% \\
(58,8 \%)\end{array}$ & - & $\begin{array}{c}62,2 \% \\
(44,4 \%)\end{array}$ & $\begin{array}{c}38,2 \% \\
(51,7 \%)\end{array}$ \\
\hline $0 \%<x$ & & $\begin{array}{c}27,3 \% \\
(43,5 \%)\end{array}$ & $\begin{array}{c}49,3 \% \\
(38,4 \%)\end{array}$ & $\begin{array}{c}7,7 \% \\
(7,7 \%)\end{array}$ & $\begin{array}{c}23,3 \% \\
(33,3 \%)\end{array}$ & $\begin{array}{c}44,2 \% \\
(38,6 \%)\end{array}$ \\
\hline $5 \%<x$ & & $\begin{array}{c}31,0 \% \\
(24,5 \%)\end{array}$ & $\begin{array}{c}3,5 \% \\
(2,2 \%)\end{array}$ & $\begin{array}{c}11,3 \% \\
(38,5 \%)\end{array}$ & $\begin{array}{c}9,8 \% \\
(16,7 \%)\end{array}$ & $\begin{array}{c}8,8 \% \\
(5,6 \%)\end{array}$ \\
\hline $10 \%$ & & $\begin{array}{c}21,7 \% \\
(15,0 \%)\end{array}$ & $\begin{array}{c}1,5 \% \\
(0,6 \%)\end{array}$ & $\begin{array}{c}13,1 \% \\
(15,4 \%)\end{array}$ & $\begin{array}{c}4,7 \% \\
(5,6 \%)\end{array}$ & $\begin{array}{c}5,4 \% \\
(2,6 \%)\end{array}$ \\
\hline$x>20$ & & $\begin{array}{l}12,8 \% \\
(8,2 \%)\end{array}$ & $\begin{array}{c}0,3 \% \\
(0,1 \%)\end{array}$ & $\begin{array}{c}67,9 \% \\
(38,5 \%)\end{array}$ & - & $\begin{array}{c}3,4 \% \\
(1,5 \%)\end{array}$ \\
\hline Total & $\begin{array}{l}\text { BRL bn } \\
\text { (\# issues) }\end{array}$ & $\begin{array}{l}54,4 \\
(147)\end{array}$ & $\begin{array}{c}234,4 \\
(1.009)\end{array}$ & $\begin{array}{c}3,9 \\
(13)\end{array}$ & $\begin{array}{c}6,4 \\
(18)\end{array}$ & $\begin{array}{c}299,2 \\
(1.187)\end{array}$ \\
\hline
\end{tabular}

Number of days with trading over the number of days since issuance. Total in BRL billions, total number of issues (in parentheses), percentage of total amount in BRL billions, and percentage of total number of issues (in parentheses). Infra bonds: bonds issued to fund priority infrastructure projects (created by Law 12,431 of 2011); Regular bonds: non-infra bonds; CVM-400: bonds issued under Instruction CVM-400 (registration required and broad distribution); and CVM476: bonds issued under Instruction CVM-476 (registration not required and distribution restricted to a limited number of professional investors). Source: Brazilian Association of Capital Market Participants (ANBIMA). Available at www. debentures.com.br and www.cvm.gov.br 
Clientele: The CVM requires underwriters to publish detailed information on the allocation of issues across groups of investors (referred to as clientele). This information is available in the anúncios de encerramento de oferta, or AEOs. We obtained AEOs for the 2015-2017 period only. We divided the clientele into two main groups: related to and non-related to the syndicate of underwriters. Related investors include all financial institutions, brokerage houses, and investment funds managed by the underwriter. Table 15 reports the allocation across clienteles. Remarkably, on average, nearly half of the proceeds are allocated to organizations/investors related to the underwriter. There is a strong crosssectional variation between the different bonds.
CVM-476 bonds tend to be allocated to related investors more than CVM-400 ones are. For instance, among regular CVM-400 bonds, 70.5\% of the proceeds go to non-related investors, while among regular CVM-476 bonds, this proportion is $45.2 \%$. For infra bonds, this difference is 82.8\% among CVM-400 bonds versus $58.1 \%$ among CVM-476 bonds. The main clienteles for Brazilian bonds are investment funds not related to the underwriter (39.4\% of the allocation) and financial institutions related to the underwriter (33.7\% of the allocation). Investment clubs, insurance companies, pension funds, and foreign investors receive less than $1 \%$ each. Curiously, investment funds managed by the underwriter receive only $2.49 \%$ of the proceeds.

Table 15

\section{Bond Allocation by Type of Issuance}

\begin{tabular}{|c|c|c|c|c|c|}
\hline \multirow{2}{*}{ Investors } & \multicolumn{2}{|c|}{ Regular bonds } & \multicolumn{2}{|c|}{ Infra bonds } & \multirow[t]{2}{*}{ Overall } \\
\hline & CVM-400 & CVM-476 & CVM-400 & CVM-476 & \\
\hline \multicolumn{6}{|c|}{ Allocation to Non-Related Investors/Organizations } \\
\hline Investment clubs & $0.00 \%$ & $0.00 \%$ & $0.06 \%$ & $0.11 \%$ & $0.01 \%$ \\
\hline Mutual funds & $58.68 \%$ & $41.24 \%$ & $6.59 \%$ & $23.09 \%$ & $39.37 \%$ \\
\hline Insurance companies & $0.46 \%$ & $0.49 \%$ & $0.06 \%$ & $0.00 \%$ & $0.44 \%$ \\
\hline Other financial institutions & $9.43 \%$ & $1.65 \%$ & $12.69 \%$ & $14.65 \%$ & $2.96 \%$ \\
\hline Other legal entities & $0.09 \%$ & $0.13 \%$ & $0.03 \%$ & $0.08 \%$ & $0.12 \%$ \\
\hline Pension funds & $1.73 \%$ & $0.87 \%$ & $0.96 \%$ & $0.15 \%$ & $0.85 \%$ \\
\hline Foreign investors & $0.00 \%$ & $0.75 \%$ & $0.00 \%$ & $0.00 \%$ & $0.66 \%$ \\
\hline Legal persons & $0.09 \%$ & $0.09 \%$ & $62.46 \%$ & $20.04 \%$ & $3.76 \%$ \\
\hline Sub-total & $70.5 \%$ & $45.2 \%$ & $82.8 \%$ & $58.1 \%$ & $48.2 \%$ \\
\hline \multicolumn{6}{|c|}{ Allocation to Related Investors/Organizations } \\
\hline Financial institutions & $14.78 \%$ & $35.74 \%$ & $6.43 \%$ & $29.04 \%$ & $33.76 \%$ \\
\hline Intermediate institutions & $12.93 \%$ & $15.37 \%$ & $9.47 \%$ & $10.52 \%$ & $14.81 \%$ \\
\hline Mutual funds & $1.82 \%$ & $2.98 \%$ & $0.77 \%$ & $0.36 \%$ & $2.49 \%$ \\
\hline Other legal entities & $0.00 \%$ & $0.65 \%$ & $0.00 \%$ & $1.38 \%$ & $0.65 \%$ \\
\hline Legal persons & $0.00 \%$ & $0.04 \%$ & $0.48 \%$ & $0.61 \%$ & $0.09 \%$ \\
\hline Sub-total & $29.5 \%$ & $54.8 \%$ & $17.2 \%$ & $41.9 \%$ & $51.8 \%$ \\
\hline Total (BRL bn) & 2.4 & 106.1 & 4.9 & 6.7 & 120.0 \\
\hline
\end{tabular}

Source: www.debentures.com.br and www.cvm.gov.br.

Sample period: 2015-2017 (not available on the CVM webpage before 2015). 


\section{Final remarks}

This article describes the microstructure of the market for corporate bonds in Brazil. We focus on the 2009-2017 period, following two major changes in the bond market: the establishment of legislation CVM-476 and infrastructure bonds. These new regulations fostered the corporate bond market in Brazil. We examined some of the main characteristics of the bond market. First, bond proceeds tend to be small $(70 \%$ of the issues are less than BRL 250 million). Also, bonds have a short maturity. For nearly 90\% of the issues, it is below 10 years. International agencies are the main ratings providers. However, they use a Brazilian-adjusted rating scale. Fixedyield bonds are rare. The vast majority of regular bonds (non-infrastructure bonds) are linked to the Brazilian interbank offered interest rate (DI or CDI). Infrastructure bonds are most commonly inflation-linked.

The most striking aspects of the Brazilian bond market concerns underwriting, allocation, and bond performance. Only two local universal banks dominate the underwriting activity. These banks and their related parties receive more than half of the allocation. This pattern is more frequent among bonds issued under CVM-476. In contrast, the majority of the CVM- 400 bonds are allocated to non-related parties.

Less than half of issues have an investmentgrade rating, and more than half are not rated at all. The exceptions are infra bonds, which almost always bear an investment-grade rating. Even more curiously, investment-grade ratings seem not to take into account recent credit events in the bond market: $20 \%$ of the issues with an investment grade come from issuers with a recently reported credit event (most commonly in the form of a renegotiation of bond terms).

The incidence of ex-post credit events (EPCEs) is high: nearly $20 \%$ of bonds. EPCEs occur mostly in the form of renegotiations of bond terms. However, strict defaults are also high, affecting $6 \%$ of bonds. Even among investmentgrade bonds, EPCEs and strict defaults are high, at $11 \%$ and $3.9 \%$ of issues. Finally, liquidity for bonds in the secondary market is low, with the exception of infra bonds issued under CVM-400.

The combination of a high frequency of renegotiations of bond terms, the frequent link to the DI rate (which is the reference for bank loans), low liquidity, and the use of CVM-476 (which waives, among other things, registration and the need for a detailed prospectus) possibly reflect the replacement of bank loans by corporate bonds. This was described by Torres and Macahyba (2014). Accordingly, banks recommend that their larger corporate clients issue corporate bonds whenever their short-term credit lines are fully used. In this process, banks offer guaranteed placement (acquiring part of the issue, if needed). The securities are placed in several portfolios under the underwriter's management, ranging from the bank's treasury to the investment funds under its management. This explains the abnormally high frequency of renegotiations of bond terms. This operation results in regulatory arbitrage. With this, banks pay fewer taxes and do not have to make provisions for credit risk. This scheme raises questions about whether an effective bond market exists in Brazil. Our results are in line with those of Hawkins (2002), who points out a conflict of interest of banks, as they are participants in the bond market.

\section{Notas}

1 In Brazil, public corporations are subject to the rules established in Law 6404/1976. Principal requirements for public corporations: bylaws in accordance with Law 6404/1976; creation of an investor relations department; appointment of an officer for investor relations; and financial statements audited by an independent auditor and made available in the public domain.

2 At first, these limits were 50 and 25 QIs, respectively. The current limits date from 2014.

3 Available at www.debentures.com.br.

4 Available at www.cvm.gov.br.

\section{References}

Biais, B., \& Green, R. (2019). The microstructure of the bond market in the 20th century. Review of Economic Dynamics, 33, 250-271. 
Carbo-Valverde, S., Rodriguez-Fernandez, F., \& Saunders, A. (2016, December). Underwriting as certification of bank bonds. Working Paper. Retrieved from https://papers.ssrn.com/sol3/ papers.cfm?abstract_id=2665917

Carvalho, A. G. (2000). Ascensão e declínio do mercado de capitais no Brasil, a experiência dos anos 90. Revista de Economia Aplicada, 4(3), 595-632.

Carvalho, A. G. de, (2005). Lei de Falência, acesso ao crédito empresarial e taxas de juros no Brasil. Revista de Economia Política, 25(1), 112-132.

Fleming, M., \& Krishnan, N. (2012, March). The microstructure of the TIPS market. FRBNY Economic Policy Review, 27-45.

Gyntelberg, J., Ma, G., \& Remolona, E. (2006). Developing corporate bond markets in Asia. BIS Papers n. 26, 13-21. Retrieved from https://www. bis.org/publ/bppdf/bispap26a.pdf

Hawkins, J. (2002). Bond markets and banks in emerging economies. BIS papers n. 11, 42-48.

Instrução CVM n. 400, de 29 de dezembro de 2003. Dispõe sobre as ofertas públicas de distribuição de valores mobiliários, nos mercados primário ou secundário, e revoga a Instrução 13/80 e a Instrução 88/88. Retrieved from http://www. cvm.gov.br/legislacao/instrucoes/inst $400 . h t m l$

Instrução CVM n. 476, de 16 de janeiro de 2009. Dispóe sobre as ofertas públicas de valores mobiliários distribuídas com esforços restritos e a negociação desses valores mobiliários nos mercados regulamentados. Retrieved from http:// www.cvm.gov.br/legislacao/instrucoes/inst476. html

Lei n. 11.101, de 9 de fevereiro de 2005. Regula a recuperação judicial, a extrajudicial e a falência do empresário e da sociedade empresária. Retrieved from http://www.planalto.gov.br/ccivil_03/_ Ato2004-2006/2005/Lei/L1 1101.htm
Lei n. 12.431, de 24 de junho de 2011. Dispóe sobre a incidência do imposto sobre a renda nas operaçôes que especifica; altera as Leis $\mathrm{n}^{\mathrm{o}} \mathrm{s}$ 11.478, de 29 de maio de 2007, 6.404, de 15 de dezembro de 1976, 9.430, de 27 de dezembro de 1996, 12.350, de 20 de dezembro de 2010, 11.196, de 21 de novembro de 2005, 8.248, de 23 de outubro de 1991, 9.648, de 27 de maio de 1998, $11.943 \ldots$ Retrieved from http://www. planalto.gov.br/ccivil_03/_Ato2011-2014/2011/ Lei/L12431.htm

Manconi, A., Neretina, E., \& Renneboog, L. (2018). Underwriter competition and bargaining power in the corporate bond. European Corporate Governance Institute (ECGI) - Finance Working Paper No. 548/2018. Retrieved from https:// papers.ssrn.com/sol3/papers.cfm?abstract_ $\mathrm{id}=3098005$

Mu, Y., Phelps, P., \& Stotsky, J. (2013). Bond markets in Africa. Review of Development Finance, 3(3), 121-135.

Ong, L. L. (2005, July). An anatomy of corporate bond markets: Growing pains and knowledge gains. International Monetary Fund working paper 05/152. Retrieved from https://www.imf. org/en/Publications/WP/Issues/2016/12/31/AnAnatomy-of-Corporate-Bond-Markets-GrowingPains-and-Knowledge-Gains-18348

Standard and Poors, 2017, 2016 Annual Global Corporate Default Study and Rating Transitions. Available at https://www.spratings.com/docume nts/20184/774196/2016+Annual+Global+ Co rporate+Default + Study + And + Rating + Transitio ns.pdf/

Torres, E. Fo, \& Macahyba, L. (2014). Os mercados brasileiro e britânico de títulos corporativos. Brasília: Confederação Nacional da Indústria. 


\section{Authors:}

1. Antonio Gledson de Carvalho, PhD, University of Illinois, Illinois USA. E-mail: gledson.carvalho@fgv.br ORCID

(iD0000-0002-3780-1149

2. Felipe Tumenas Marques, Doctor, EAESP-FGV, São Paulo, Brazil. E-mail: tumenas@ufba.br ORCID

$$
\text { (D)0000-0001-8327-4215 }
$$

\section{Contribution of each author}

\begin{tabular}{lll}
\hline Contribution & Antonio Carvalho & Felipe Marques \\
\hline 1. Definition of research problem & $\sqrt{ }$ & $\sqrt{ }$ \\
2. Development of hypotheses or research questions (empirical studies) & $\sqrt{ }$ & $\sqrt{ }$ \\
3. Development of theoretical propositions (theoretical work) & $\sqrt{ }$ & $\sqrt{ }$ \\
4. Theoretical foundation / Literature review & $\sqrt{ }$ \\
5. Definition of methodological procedures & $\sqrt{ }$ \\
6. Data collection & & $\sqrt{ }$ \\
7. Statistical analysis & $\sqrt{ }$ \\
8. Analysis and interpretation of data & $\sqrt{ }$ \\
9. Critical revision of the manuscript & $\sqrt{ }$ \\
10. Manuscript writing & $\sqrt{ }$ \\
11. Other (please specify which) & & $\sqrt{ }$ \\
\end{tabular}

